\title{
Festival leaders: charisma and inebriating substances (IS)
}

\begin{abstract}
The holiday is considered as an independent sphere of social life the opposite work. In traditional society, the holidays are not allotted less time than work. The work contributed to the development of rational thinking, while resting on a holiday mythological (magical) thinking. Labor leaders, whose authority rested on their production talents, radically different from the leaders of the holiday. The last has a unique psychological constitution, high nervous excitability, ability to fall into a trance. Their activities to direct a ceremony was closely associated with the use of intoxicating substances. Falling into a trance (an ecstasy) they generate in their minds fantastic images (phantasms), of which a picture of the world of primitive man is formed.
\end{abstract}

Keywords: holiday, labour, feast leaders, rational thinking, mythological thinking, intoxicant substances
Volume 2 Issue 4 - 2018

\author{
Bocharov Victor Vladimirovich \\ Saint Petersburg State University, Russia
}

Correspondence: Bocharov Victor Vladimirovich, Saint Petersburg State University, Russia, Tel 89214273199, Email victana2007@rambler.ru

Received: June 22, 2018 | Published: July 17, 2018

\section{Introduction}

Friedrich Engels is known to have praised «labour» that «created man himself». This approach domineers in modern science. The author shows in this article that «festivals» as opposed to labour played no less a role in this process.

\section{On labour, festivals, and thinking}

Indeed, it was thanks to labour that man became bipedal in order to free the hands for work activities (crafting tools, etc.). F.Engels explained the appearance of speech (language) by the fact that the members of the primary labour collective needed to communicate with each other. This, in its turn, «transformed the ape brain into the human one». Development of the brain's «ability to abstract and draw conclusions impacted then labour and language, pushing both to further development.... At the end, the author sums it up: «Thanks to joint activities of the hand, organs of articulation and the brain not only in separate men, but in the society on the whole, the hominids asquired the ability to perform more and more complicated operations, set up higher and higher goals, and achieve them». ${ }^{1}$

Modern understanding also connects the development of rationality with production activities (labour). While rationalization of thinking secured survival of humanity, «Reliable recognition or relevant goals, i.e. significant for this individual... if...behavioral responses are adequate to the objects' features, means that perception may serve as reliable information basis for activity...this is preserved and reinforced in the course of evolution, since this was simply necessary... for survival». ${ }^{2}$

Ethnographic materials on the most «primitive» communities (bushmen, the Eskimos, etc.) show that the people most talented in some type of activity (fishermen, hunters, warriors) acted as Labour Leaders. And their influence was limited to this particular sphere, not exceeding its borders. Moreover, there is a lot of evidence that any effort of such leaders to expand their influence to the everyday life was rigorously suppressed by the community. Thus, labour really played an important role in the evolvement of man, defining the mental processes' evolution towards rationalization, but it also envisaged the establishment of the type of leadership based on certain capabilities in specific sphere of production activity.
However, mythological (magical) thinking, with its roots in the unconscious layers of the human psyche, played no less a role in this process (J.G.Frazer, L.Levy-Bruhl, F.Boas, etc.). It gave rise to fantastic meanings and images that formed the world view of the ancient people. Already the Neanderthal burials found in the caves of France (La Chapelle aux Saints, Lascaux, Les Trois Freres), contained the objects that demonstrate that their world view included the World of the Dead. Their phantasms may be seen in petroglyphs depicting people with bird heads, mysterious figures combining human legs and trunk, horse's tail, bear's paws, chamois' beard, owl's beak, wolf's eyes, deer's horns and ears, or a cow with buffalo's head [Ibid.]. The same images may be found in any folklore (myths, Russian epics, fairy tales, etc.), where the border line between man and nature is rather conditional, and the subjects may easily transform into each other or freely communicate in human language. Human ancestors may become plants or animals (totems). So, at the very early stages of sociogenesis the human thinking could manipulate «the phenomenal world and anticipate a new product on the basis of old elements» [Ibid.].

If the rational thinking with new knowledge gives rise to new questions and produces new problems, the mythological one constructs reality from things known and vice versa makes this reality holistic and eliminates any questions or problems, «Mythological detachment is a detachment from discrete, separate existence of things, their unification in a new domain, a kind of a living whole..., that attributes them with a soul...myth is not a fiction, not a make-believe, but $a$ reality realized in a special way». ${ }^{3}$

Thus, we see two ways of understanding the world, a rational one based on identification of real links and relations between the surrounding objects, as well as between them and the human beings; and irrational/mythological one in which these links are animated and permeated with (magic) Power. In the result, a fantastic world view had been forming thanks to which nevertheless man progressed as well. This world view convinced man that he was predominant over nature, which he subdued to his will by way of magic practices, e.g. conjuring the rain or "guaranteeing" good luck in hunting.

Ethnographic materials collected by the anthropologists allow us to single out two relatively independent spheres of social being, 
labour and festivals, and various types of thinking associated with them. These types opposed each other, which are reflected in many cultures and religions by the ban to work on festive days.

By festival we should understand all extrautilitarian activities which saturated the primary collective, viz. rituals, ceremonies, festive performances. They had various goals: rites of passage, restoration of health, communication with ancestors, dedicated to the change of natural cycles and many others. Festive ceremonies frequently lasted from the end of one labour season until the beginning of the next one. They «endlessly followed one another...sometimes up to fivesix ceremonies per day....The number of festive days among various nations could even...exceed the number of ordinary working days». ${ }^{4}$ On the whole, communities that seemed to struggle for survival «spent main efforts not to increase tangible stability, but for extrautilitarian sphere...». ${ }^{5}$

M.Moss in his "Essay on Seasonal Changes in the Eskimos Societies" (1906) wrote about distinct differentiation between festivals and labour in the life of traditional societies, and their association with various types of thinking, «All myths that fill the consciousness of the Eskimos in the winter-time, seem too forgotten during summer. Life seems to be subject to secularization... its ritualism is brought to a minimum. While in the winter dwelling the Eskimos reside in the condition of a constant religious excitement.... Even insignificant events demand a more or less ceremonial participation of a shaman.... Spectacular public sessions of shamanic conjurations take place on a regular basis.... In short, the whole winter life may be describes as one long festival... the common mishaps... are explained by a violation of some ritual ban... life in the winter... is exclusively collective». ${ }^{6}$

The sphere of labour was initially giving birth to social individualism, with hunting, as it goes, especially contributing to this, since it required creative solutions from a man, «being aware of the individual self as opposed to others»». ${ }^{7}$ It was inevitably accompanied by the psychic acts of «not doing something $\rangle^{8}$ that significantly transformed individual psychology, and awakened the practical intellect, purposeful rational thinking, but also initiated corrosive processes in the collective psychology.

The festival, on the other hand, was associated with the coming of chaos, violations of taboos, verbal, food, sexual, etc., that were strictly observed during workdays; in that period, everything turned upside down. Thus, by denying any bans connected with the slowdown of natural psychophysiological reactions, the festival brought the man back to his psychological origin, to the natural expression of feelings, emotions, and moods. Opposite to labour it was connected with irrational, ecstatic state. A positive emotional background of "joy and merrymaking" was common for all festive procedures, since all worries generated in the human consciousness by rational thinking (labour) were eliminated. What differentiated the festival from simple rest or entertainment was its solemnly sacral nature that was always sanctified by the World of Ideals (Bakhtin).

\section{Festival leaders and charisma}

A festival, being a special sphere of social being, had its own leaders as well; the latter were absolutely different from the labour leaders. Such leaders led multiple festive ceremonies after the completion of the labour season. These were various medicine men, prophets, sorcerers, and shamans who, as expected, had a special gift (charisma) to impact the surrounding objects and people, subduing them to their will. They were characterized by some «anomalies», physical, social, or mental. For example, they might have had various deformities or malformations, like birth-marks («tsar's marks»), lichens, cross eye, etc. As a rule, they were not married, had no children, or were orphans themselves, expressed their thoughts using unclear (allegoric) words. ${ }^{1}, 9 \mathrm{~V}$. Bogoraz wrote that «most of the shamans were nervous, easily excitable people, often on the verge of madness». ${ }^{10}$ Thanks to such mental organisation they could easily turn on and had «a special ability to ecstatic experience». ${ }^{2}, 11$

The researchers also noted that these people usually had outstanding artistic skills in dance, music, public speaking, writing of songs and hymns. Some «medicine men, sometimes women well versed in love sorcery», i.e. people «playing central roles during various ceremonies» said that «new songs dawn upon them in sleep, being the gifts of totems, spirits, deceased relatives or spirits of animals killed when hunting». ${ }^{12}$

Such practices used by the festival leaders helped them to achieve the ecstatic state which encompassed then all the participants of the festival. Dance was an important tool of influence, and the carriers of traditional cultures were taught this from early childhood [Ibid.]. Dance was an integral part of all ceremonies. ${ }^{3}$ The state of «madness»» achieved during the dance helped, as it seems, to free the archaic consciousness from the influence of instinctive links, and gave rise to those phantasms from which the world view was constructed: «Many feelings and emotions (aesthetic and others) appear first as body functions until the man by way of rational thinking processes does not sublimate them to the consciousness level». ${ }^{13}$

The shamanistic rituals described by Bogoraz $^{10}$ give us an understanding of how the shamans «infected» the other participants of the ritual, relaying, most probably, the images that appeared in his brain, «The shaman is singing alone all the time.... However, from time to time one of the audience cries out an interjection expressing surprise, or "sure, or right". All these exclamations demonstrate complete approval from those present.... The Chukchee have a special name for such exclamations, "cry out in response". Without such responsive cries a Chukchee shaman considers he incapable to conjure spirits. The assistance from the audience in the form of exclamations is crucial for Chukot story-tellers as well.... From time to time, they (participants of the festival, V.B.) pick up the shaman's

${ }^{1}$ Chukchee considered the shamans who entered a homosexual marriage the most powerful, «the indigenes fear the transformed people much more than ordinary shamans». ${ }^{10}$

${ }^{2}$ Bekhterev VM. Studied the leader of one of the religious sects who would start to tremble ("shake") during the common prayers, and all those present also had convulsions and jerks. He came to the conclusion that the former impressed auditory hallucinations and smells upon the audience. First, he himself experienced such hallucinations and then they were transferred (impressed by him) to his followers. The reason for him himself to experience such feelings were explained by the peculiarities of his psyche, «One cannot doubt that the illusion of the senses that develop under the impact of subcortical excitation often affect the psychic sphere, the same as any other outside suggestion, and cause inclinations and impulses which the person cannot counteract, as well as the impression of such suggestions». ${ }^{14}$

${ }^{3} \mathrm{~A}$ famous Indian spiritual leader and mystic Bhagavan Sri Rajneesh (Osho), who became known throughout the world thanks to his meditative practices that led to «total liberation and enlightenment», paid great tribute to dance as a psychodelic tool. For the dance, «your whole being is needed. And the moment comes for sure when dance becomes insane...the more energetic you are, the deeper you submerse into dance, the less reasoning is left...dance... is a technique to push you out into the unknown. At some moment, it won't be you dancing any more, but the dance will take over. And you will be thrown towards an unknown source». ${ }^{15}$ 
chant and sing together with him.... Often the shaman would imitate the cry of some animal or bird that is considered to be his patron... the pitch of the voice....after the appearance of supernatural beings becomes harsh, coarse, and unnatural». ${ }^{10}$

\section{Festival leaders and IS}

The festivals were always accompanied by consumption of IS. The pioneering explorers have always been impressed by the fact that even the most «primitive tribes» of the Americas, Australia, Oceania, Africa, and Siberia knew how to make IS, which they smoked, drank and snuffed. They overcame all possible difficulties and «discovered» their own way of preparing the IS. For example, Bushmen cattle herders who did not have sorghum from which the surrounding tribes of farmers made alcohol, learned to make it from bee honey. This was noticed by a missionary to his great surprise. ${ }^{16} \mathrm{He}$ also paid attention to the fact that the African Zulus, after the end of labour season, «From May to August... survived practically on beer only...» [Ibid:185].

IS everywhere had a sacral status, while the inebriated state was considered to be sacred, the one in which people were supposed to come into contacts with supernatural beings (spirits, ancestors, gods, etc.). In ancient myths, IS making the gods immortal. In Ancient Greece, it was nectar («overcoming death»), while the god of wine and wine-making Dionysus, a son of Zeus. The Romans connected IS with thunder-bearing Jupiter. IS could be seen as the incarnation of the deity himself, e.g., hallucinogenic drink soma was considered to be one of the forms of God Soma. ${ }^{17}$ In Norse sagas evil dwarfs that killed the wandering minstrel Kvasir, prepared «kvas» from his blood, a heavenly drink inspiring the poets. Thus, mythical features of "prophetic people (Kvasir and Brage) transferred then to Scandinavian skalds that presented during feasts...» [Pryzhov 1992: 265]. For Chukchees, «inebriating fly agarics represented a "special tribe".... Fly agarics take a person by the hands and to the Land of the Dead, showing him everything there is there and performing the most incredible things with the man.... They visit the world where the dead preside». ${ }^{10}$

If in mythologies IS were connected with gods, in traditional cultures it were the festival leaders who took care of them and thus simplified entering into a state of trance for the participants of the festival. In the result, the ceremonies resembled "collective ecstasy sessions, boisterous emotional discharge». ${ }^{19}$ In Tungus culture, «The shaman starts beating the tambourine, sing and dance. He is jumping higher and higher. His assistants together with the spectators pick up the chant's refrain. The shaman stops for a minute, drinks a glass of water, smokes several pipes, and resumes the dance. Gradually, he heats up to such an extent that falls down motionless, in a state of ecstasy. If he does not come to his senses, he is sprinkled with blood three times. The shaman stands up and starts speaking in a high voice, and answers the questions asked by two or three people in the form of a chant. The body of the shaman is now the dwelling of the spirit, and it is the spirit that answers the questions, since the shaman himself is in the underworld. When he comes back, everybody welcome his return from the world of the dead by shouts of joy». ${ }^{11}$

It is evident from the materials, how the leader of festival uses IS as an additional stimulator for the participants to achieve the desired state, "When prayers do not help, he offers them vodka. and the session livens up.... The shaman depicts the return road, he dances and cries out, until he falls down unconscious» [Ibid.].

The role of IS in achieving the ecstasy that brought to life phantasms in the mind of the festival leaders, seems to be huge.
Proof to this is their omnipresence in sacral status in all traditional cultures. Probably, in order to liberate the mind from the instincts that were still binding it, and to mobilize the creative energy, the external biochemical stimulator was needed. It looks like the alcohol is playing a similar role in our days, «Ecstasy is "exiting your own self", i.e. temporary self-elimination of the personality. At that, Dionysus does not only destructs, but also creates the fluid forms of individuation». ${ }^{20}$

\section{Conclusion}

One may clearly see the correlation between «archaic» consciousness (unconscious), ecstasy, and IS in modern days' Melpomene followers. K. Chukovskiy wrote about the futurists and «the lowest stage of ecstatic excitement, with a passion to write new unprecedented words, and such words are practically always the same among savage shamans... eunuchs, runners, or jumpers...» manifested in their creative works. ${ }^{21}$

Reflecting creators realize that in their creative work they appeal to «archaic» layers of the audience psyche. S. Eisenstein matched perception of films with ecstasy, the essence of which is «ascension towards the roots...towards the earliest stages of civilization». ${ }^{22}$

The link between artistic (literary) creative activities and IS is also prominent, «It was customary among our intelligentsia.... It was impossible to grasp the meaning of life without drinking; the more you drink, the clearer you see the horizons of your life; the more senseless is your mumbling, the more sensible your existence.... Space and vodka act the same - the body becomes free of gravity. Everybody drank...mediocre people and men of genius. Tvardovskiy drank on a noble scale. Sholokhov drank massively. The chief writer of the country Fadeev also drank.... The best writer of the country Andrei Platonov drank as well...Akhmatova went in for vodka either». ${ }^{23}$

This connection is fixed in the philistine mind. The namesake of the autoe of the previous passage in his poem "Moscow-Petushki" cites a laymen dialogue ${ }^{24}$ the alternative of which many must have heard themselves. Venichka's fellow passengers on the commuter train start a discussion and «drawing upon the facts» persuade each other that artistic creative activity is closely connected with alcohol, «What about Kuprin and Gorkiy, those were always on a drink... And the last words of Anton Chekhov before he passed away?... "Dive me some champagne". And only then he died".

"And Friedrich Schiller, to say nothing of dying, he could not live without the champagne.... One glass, and the whole act of tragedy are ready. Five glasses and the complete tragedy in five acts is done". Gogol drank vodka from a pink goblet...». ${ }^{25}$

\section{Acknowledgements}

None.

\section{Conflict of interest}

Author declares there is no conflict of interest.

\section{References}

1. Engel's F. Rol truda v protsesse prevrashcheniya obezyany v cheloveka. Dialektika prirody M, editor. 1982:144-156.

2. Kliks F. Probuzhdayushcheesya myshlenie. U istokov chelovecheskogo intellekta. M Progress. 1983.

3. Losev AF. Dialektika mifa. Mif Chislo Sushchnost. Mysl M. 1994:67. 
4. Abramyan L. Primordial Festivals. Erevan AN, editor. 1983.

5. Baiburin AK. Rituals in Traditional Cultures. Nauka L, editor. 1991.

6. Zhigulskiy K. Festival and Culture. Progress M. 1985.

7. Andreev IL. Origins of Man and Society. Mysl M. 1982.

8. Sorokin P. Chelovek, tsivilizatsiya, obshchestvo. M Politizdat. 1992.

9. Bocharov VV. The Origins of Power, anthropology of Power. A TextBook on Political Anthropology. State University Publishing House. V1 the Power in and Anthropological Discourse. 2006;2:192-204.

10. Bogoraz VG. The Chukchee. 1939; p. II.

11. Eliade M. Shamanizm: arkhaicheskie tekhniki ekstaza. Kiev: Sofiya 2000.

12. Artyomova O Yu. Personality and Social Norm in the Early Primitive Society. 1987.

13. Pasto TA. Zametki o prostranstvennom opyte $v$ iskusstve. Semiotika iskusstvometriya. 1972.

14. Bekhterev VM. Heterosuggestion and Its Role in the Social Life. 1908.
15. Osho. Meditatsiya-iskusstvo vnutrennego ekstaza. 2009.

16. Bryant A. The Zulu People Before the Europeans Came. Doreign Literature Publishing House. 1953

17. Toporov VN. Opyanyayushchii napitok. Mify narodov mira: Entsiklopediya. Sovetskaya entsiklopediya. 1980.

18. Pryzhov IG. Istoriya kabakov v Rossii. Druzhba narodov. 1992.

19. Krasheninnikov SP. Opisanie zemli Kamchatki. AN SSSR. 1949

20. Ivanov Vyach. Dionysus and Praodionysism. STP. 1994.

21. Chukovskii K. Futuristy. SPB. 1922.

22. Eizenshtein S. Izbrannye proizvedeniya. 1964;6:2

23. Erofeev Victor. Vodka and the Intelligentsia.

24. Bocharov VV. Russian Festival-Drinking Culture and the Power anthropological aspect. Journal of Sociology and Social Anthropology. 2016;4(64):178-191

25. Erofeev V. Moscow-Petushki. A Novel. Knizhnaya Palata. 1989 